\title{
Cost, Return, and Profitability of Vegetable Seed Production in Western Rukum, Nepal
}

\author{
Melsan Shrestha ${ }^{1}$, Shiva Chandra Dhakal ${ }^{2, *}$ \\ ${ }^{1}$ United Mission to Nepal, Kathmandu, Nepal \\ ${ }^{2}$ Department of Agricultural Economics and Agribusiness Management, Agriculture and Forestry University, Rampur, Chitwan, Nepal
}

Email address:

scdhakal@afu.edu.np.com (S. C. Dhakal)

${ }^{*}$ Corresponding author

To cite this article:

Melsan Shrestha, Shiva Chandra Dhakal. Cost, Return, and Profitability of Vegetable Seed Production in Western Rukum, Nepal. International Journal of Agricultural Economics. Vol. 5, No. 5, 2020, pp. 172-180. doi: 10.11648/j.ijae.20200505.14

Received: August 20, 2020; Accepted: September 3, 2020; Published: September 17, 2020

\begin{abstract}
Vegetable seeds are high-value and low-volume products, and one of the promising sub-sectors for improving agricultural production, poverty reduction, and food security in Nepal. It is an extremely prioritized sector for uplifting livelihood of rural people. Due to an increase in the area under vegetable production for both the main and offseason, and replacement of locally produced seeds by the improved varieties, there is an increase in the vegetable seed demand. Nevertheless, only $50 \%$ of the national demand for vegetable seeds was met by domestic production. Western Rukum has long been known as the area with the most potential for vegetable seed production in Nepal. In this regard, this study was executed to assess the cost, return, and profitability of major vegetable seed production in the district. Altogether 201 sample households were selected using simple random sampling in 2017. The primary data were collected from household survey using a pretested semi-structured survey schedule and verified from a focus group discussion. The study showed that 13 types of vegetable seeds had been producing in the study area. Among them, onion seed, cauliflower seed, radish seed, and pea seed were primarily grown. The research revealed that all the major four vegetable seeds were profitable subsectors, where, cauliflower was the most profitable vegetable seed crop with B:C 1.78, followed closely by onion seed (1.68), radish seed (1.52), and pea seed (1.27). In contrast, the onion seed had the highest gross margin (NPR.121,682) per ha followed closely by cauliflower seed (NPR.117,136), radish seed (NPR.47,640), and pea seed (NPR.27,131). There is an opportunity to meet national demand, and to boost the local economy by promoting vegetable seed enterprises in the study area. The concerned stakeholders and policymakers need to focus on enhancing market linkage and farmers' technical know-how to promote vegetable seed production.
\end{abstract}

Keywords: Vegetable Seed, Cost, Income, Profitability, Nepal

\section{Introduction}

Nepal is principally an agrarian country. The agriculture sector accounts for $29.37 \%$ of national GDP and is the main income source for a majority $(65.7 \%)$ of the population $[8$, 12]. In this regard, vegetable production is one of the major subsectors, which accounts for $9.7 \%$ of the Agriculture Gross Domestic Product (AGDP) in Nepal [1]. Both the area and production of vegetables in Nepal has increased since 2002 to 2014 [11]. Nevertheless, in Nepal, only $50 \%$ of the national demand for vegetable seed was met by domestic production over the last decade [9].
Vegetable seeds are high-value and low-volume products, and one of the promising sub-sectors for improving agricultural production, poverty reduction, and food security in Nepal [10]. It is an extremely prioritized sector for rural economy enhancement [17]. Due to the increasing area under fresh vegetable production, demand for vegetable seed is also increasing per year [15]. The total seed production of vegetables in Nepal has increased dramatically from $9 \mathrm{Mt}$ in 1975 to $1127 \mathrm{Mt}$ in 2015 . This remarkable change in the vegetable seed sector was due to the increased involvement of the private sector. Similarly, seed requirement also has significantly increased from $293 \mathrm{Mt}$ to $2382 \mathrm{Mt}$ in the same period. This increment was due to an increase in the area 
under vegetable production for both the main season and offseason as well as due to the replacement of locally produced seeds by the improved varieties. However, the rate of increment of seed production was slower in comparison to the increment of seed requirement. As a result, the gap was increasing [3].

In Rukum district, which is currently divided into Eastern Rukum and Western Rukum, the vegetable seed growing area falls under the Western Rukum. This district has long been known as the area with the most potential for vegetable seed production in Nepal [16]. Rukum district produced $62 \mathrm{Mt}$ vegetable seed in 2014, $62 \mathrm{Mt}$ in 2015, and $110 \mathrm{Mt}$ in 2016 [5], which shows the increasing trend. Western Rukum produced $9.75 \%$ of the total national vegetable seed production in 2016, ranking the first among the 77 districts of Nepal [16]. The diverse agro-climate from warm sub-tropical to cool temperate Himalayan range poses immense scope of growing various vegetable seed in Rukum [13]. Thus, the district has a great opportunity not only to meet the increasing domestic demand but also to expand export markets of vegetable seeds [6]. In these contexts, this study was conducted to assess the cost, return, and profitability of vegetable seed production in the district.

\section{Materials and Methods}

\subsection{Selection of the Study Area}

This study was conducted in the Western Rukum district of Nepal. The district was the highest contributor to vegetable seed production among all the districts in Nepal [10]; For this reason, it was selected purposively for the study. Among the six local governments in the district, two urban municipalities namely Musikot and Chaurjahari; and two rural municipalities namely Sani Bheri and Triveni were identified as key vegetable seed production areas by District Agriculture Development Office, Rukum [4]. Hence, within the district, all these four municipalities were purposively selected for the study.

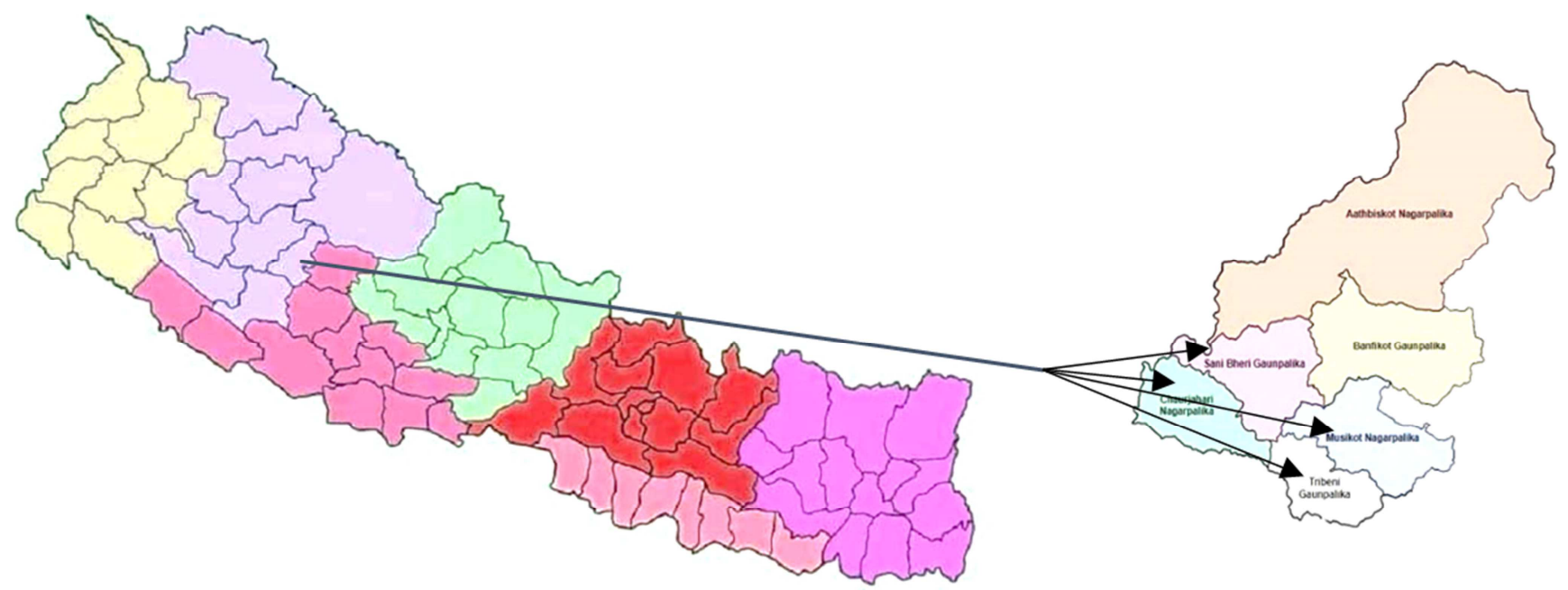

Figure 1. Map showing the study area of research in Western Rukum district of Nepal.

\subsection{Study Population, Sample Size, and Sampling Frame}

All the vegetable seed growing farmers of the study area were considered as the study population. In the study area, 1010 vegetable seed producers were associated with 44 farmers groups [16]. A sample size of 201 was deemed adequate for the study. From each of the four municipalities, among the total of 201 households participating, 72 in Musikot municipality, 96 in Chaujaharai municipality, 17 in Saniveri rural municipality, and 16 in Triveni rural municipality was considered based on proportional to the size of the vegetable seed growers in those municipalities. The samples were selected by using simple random sampling technique. Following, household survey was conducted to collect primary data using personal interview schedule.

\subsection{Selection of Vegetable Crops}

Altogether 13 several types of vegetable crops had been growing in the district for seed production. All of them were ranked by using a matrix ranking method in a focus group discussion, and four topmost ranked vegetable seed namely onion seed, radish seed, cauliflower seed, and pea seed were selected for the study purpose.

\subsection{Cost of Production}

The cost of production of four vegetable seeds was studied by considering the variable cost incurred in vegetable seed production. The variable costs were the expenses incurred for labour, seed, chemical fertilizers, organic manures, pesticides, and other (irrigation, packaging, harvesting, and marketing materials) cost. The total variable cost of production was calculated by summing up all expenditures on variable inputs.

\subsection{Gross Margin Analysis}

Gross margin, for seed production, was calculated by differencing gross return and the variable cost incurred. It is the simple and quick method of analysing farm business for 
profitability. The gross margin of the major vegetable seed produced in the study area was calculated by using the formula:

Gross margin=Gross Return (GR) - Total Variable Cost (TVC).

Where,

$\mathrm{GR}=\sum(\mathrm{Pi} \times \mathrm{Qi})$

$\mathrm{Qi}=$ quantity of vegetable seed sold $(\mathrm{kg})$

$\mathrm{Pi}=$ price of vegetable seed (NPR $/ \mathrm{kg}$ )

Total variable cost $(\mathrm{TVC})=$ summation of cost of all variable cost [2].

\subsection{Benefit-cost Analysis}

The undiscounted benefit-cost analysis was calculated by using the formula:

$$
\text { Benefit }- \text { cost ratio }(\mathrm{B}: \mathrm{C})=\frac{\text { Gross Return }}{\text { Total Variable Cost }}
$$

For calculating gross return, income from the sale of vegetable seed was accounted. Whereas, the cost of production was calculated by summing all the variable costs incurred in the production process [7].

\subsection{Resource Productivity}

A linear regression model was used to determine the resource productivity of major vegetable seed, which was analysed by the following formula.

Linear $\mathrm{Y}=\mathrm{a}+\mathrm{b} 1 \mathrm{X} 1+\mathrm{b} 2 \mathrm{X} 2+\mathrm{b} 3 \mathrm{X} 3+\mathrm{b} 4 \mathrm{X} 4+\mathrm{b} 5 \mathrm{X} 5+\mathrm{b} 6 \mathrm{X} 6+\mathrm{U}$

Where,

$\mathrm{Y}=$ Income from vegetable seed

$\mathrm{X} 1=$ Cost of labour per hectare (NPR)

$\mathrm{X} 2=$ Cost of seed per hectare (NPR)

$\mathrm{X} 3=$ Cost of fertilizers per hectare (NPR)

$\mathrm{X} 4=$ Cost of manure per hectare (NPR)

$\mathrm{X} 5=$ Cost of pesticides per hectare (NPR)

$\mathrm{X} 6=$ Other costs per hectare (NPR)

$\mathrm{U}=$ the error term

Besides, the ' $\mathrm{a}$ ' is a constant term and $\mathrm{b} 1, \mathrm{~b} 2, \mathrm{~b} 3, \mathrm{~b} 4, \mathrm{~b} 5$, and b6 are the regression co-efficient of $\mathrm{Y}$ with respective explanatory variables $\mathrm{X} 1, \mathrm{X} 2, \mathrm{X} 3, \mathrm{X} 4, \mathrm{X} 5$, and $\mathrm{X} 6$, respectively [14].

\section{Results and Discussion}

\subsection{Socio-economic Characteristics of Respondent Households}

In the study area, about $86 \%$ of household heads were found male, whereas the female-headed households were only about $14 \%$.

The mean age of the household head was 48.3 years with a minimum of 22 and a maximum of 80 years. While, the average schooling years of the household head was 5.0 year, and on an average 3.95 members of a household had taken any formal education.

Likewise, about $93 \%$ of the households were primarily engaged in agriculture; for the remaining 7\%, agriculture was only a minor occupation for the household. The average family size was 6.0. Similarly, among the household members, 3.9 were an economically active member of the age category in between 15 to 59 years. Whereas, the dependency ratio which is the ratio of the dependent population of the age group below 15 years and above 59 years to the economically active population was found to be 0.35 in the study area. The following Figure 2 shows the gender of the household head. Similarly, Table 1 presents the socio-economic characteristics of the respondent households.

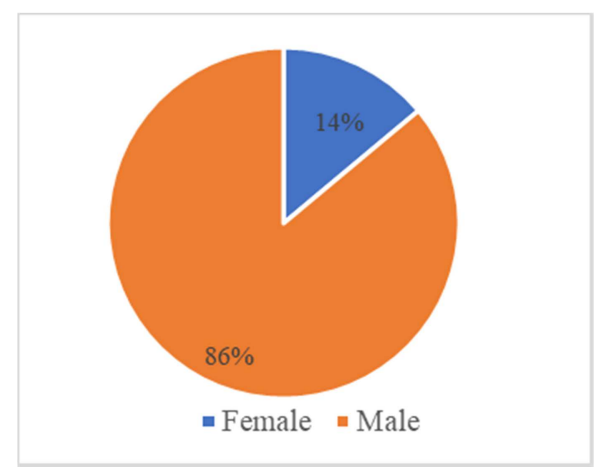

Figure 2. Gender of the household head of the respondent households.

Table 1. Socio-economic characteristics of the respondent households.

\begin{tabular}{|c|c|c|c|c|}
\hline Variable & Minimum & Maximum & Average & Standard Deviation \\
\hline Age of the household head (Year) & 22 & 80 & 48.3 & 12.44 \\
\hline Years of schooling of the household head (Year) & 0 & 18 & 4.99 & 5.27 \\
\hline Economically active member (Number) & 0 & 9 & 3.89 & 1.77 \\
\hline Educated member in the household (Number) & 0 & 11 & 3.95 & 1.73 \\
\hline Household size (Number) & 2 & 15 & 6 & 2.21 \\
\hline
\end{tabular}

(Source: Field Survey 2017).

\subsection{Area, Production and Productivity of Major Four Vegetable Seeds in the Study Area}

Among the 201 surveyed households, the total number of onion seed (Red Creole) growers was 89, cauliflower seed
(Kathmandu Local) grower was 22, radish seed (Mino Early) grower was 77, and pea (Sikkime Local) grower was 26.

The average of the area under-onion seed cultivation by a household was 0.08 ha with $162 \mathrm{~kg} / \mathrm{ha}$ productivity. Similarly, that of under cauliflower seed production was 0.03 
ha with productivity $213 \mathrm{~kg} / \mathrm{ha}$. Whereas, radish seed was cultivated in an average of 0.08 ha by a household with 272 $\mathrm{kg} /$ ha productivity. Likewise, on average, a household was cultivating pea seed in 0.03 hectares of land, which had 479 $\mathrm{kg} /$ ha productivity. The result revealed that among the four- vegetable seeds, pea had the highest productivity followed by radish, cauliflower, and onion respectively.

The area of cultivation, production, and productivity of these major four vegetable seeds are presented in Table 2 below.

Table 2. Area, production, and yield of major vegetable seeds.

\begin{tabular}{|c|c|c|c|c|}
\hline Vegetable seed & Minimum & Maximum & Average & Standard Deviation \\
\hline \multicolumn{5}{|l|}{ Onion seed $(\mathrm{N}=89)$} \\
\hline Area (ha) & 0.05 & 0.2 & 0.08 & 0.04 \\
\hline Production $(\mathrm{kg})$ & 9.00 & 85.00 & 33.76 & 18.10 \\
\hline Productivity $(\mathrm{kg} / \mathrm{ha})$ & 147.68 & 984.5 & 424.28 & 162.42 \\
\hline \multicolumn{5}{|c|}{ Cauliflower seed $(\mathrm{N}=22)$} \\
\hline Area (ha) & 0.05 & 0.10 & 0.07 & 0.03 \\
\hline Production (kg) & 12.00 & 72.00 & 41.91 & 18.28 \\
\hline \multicolumn{5}{|l|}{ Radish seed $(\mathrm{N}=77)$} \\
\hline Area (ha) & 0.05 & 0.51 & 0.13 & 0.08 \\
\hline Production $(\mathrm{kg})$ & 20.00 & 500.00 & 112.09 & 80.38 \\
\hline Productivity $(\mathrm{kg} / \mathrm{ha})$ & 393.00 & 1637.50 & 883.87 & 272.41 \\
\hline \multicolumn{5}{|l|}{ Pea seed $(\mathrm{N}=26)$} \\
\hline Area (ha) & 0.05 & 0.15 & 0.08 & 0.03 \\
\hline Production $(\mathrm{kg})$ & 30.00 & 200.00 & 78.04 & 48.41 \\
\hline
\end{tabular}

(Source: Field Survey, 2017)

\subsection{Income and Cost of Production of Major Vegetable Seeds in the Study Area}

The farm income from one $\mathrm{kg}$ of onion seed was the highest (NPR 721) among the four-vegetable seeds followed by cauliflower seed (NPR 477), radish seed (NPR 172), and pea seed (NPR 128). Similarly, the per kg cost of production for this four-vegetable seeds also ranked in the same order.

By the same token, both the household income and cost of production in one hectare of land followed the same order. The household income of onion seed, cauliflower seed, pea seed, and radish seed from a hectare of land was NPR 306,205, NPR 270,366, NPR 152,973, and NPR 131,440, respectively. Whereas, the cost per hectare of onion seed, cauliflower seed, pea seed, and radish seed were NPR 184,523, NPR 153,229, NPR 105,333, and NPR 101,595, respectively.

The income from both one $\mathrm{kg}$ of seed as well as from one hectare of land was highest from the onion seed followed by cauliflower seed, radish seed, and pea seed. The income and cost of the major vegetable seed per hectare as well as per $\mathrm{kg}$ are depicted in Table 3.

Table 3. Income and cost of major vegetable seed production.

\begin{tabular}{lllll}
\hline Vegetable seed & Minimum & Maximum & Average & Standard Deviation \\
\hline Onion (N=89) & & & & $25,117.19$ \\
Income (NPR/ha) & $103,372.50$ & $689,150.00$ & $306,205.31$ & 41.21 \\
Price (NPR/kg) & 700 & 800 & 721.35 & $2,793.38$ \\
Cost (NPR/ha) & $89,097.25$ & $377,457.30$ & $184,523.51$ & 142.96 \\
Average cost (NPR/kg) & 245.92 & 866.67 & 464.79 & $92,098.14$ \\
Cauliflower seed (N=22) & & & & 25.48 \\
Income (NPR/ha) & $117,900.00$ & $530,550.00$ & $270,366.14$ & $40,740.29$ \\
Price (NPR/kg) & 450 & 500 & 477.27 & 97.94 \\
Cost (NPR/ha) & $102,376.50$ & $60,362.50$ & $153,229.81$ & $46,941.69$ \\
Average cost (NPR/kg) & 173.67 & 616.67 & 289.31 & 4.26 \\
Radish seed (N=77) & & & & $33,565.78$ \\
Income (NPR/ha) & $70,740.00$ & $278,375.00$ & $152,973.25$ & 36.46 \\
Price (NPR/kg) & 170 & 180 & 172.34 & $105,333.10$ \\
Cost (NPR/ha) & $49,370.63$ & $216,805.00$ & 124.01 & $62,445.20$ \\
Average cost (NPR/kg) & 58.8 & 235.71 & & 19.74 \\
Pea seed (N=26) & & & $131,440.22$ & $34,288.22$ \\
Income (NPR/ha) & $49,225.00$ & $285,505.00$ & 128.46 & 26.1023 .35 \\
Price (NPR/kg) & 120 & 225 & $101,595.35$ & 105.86 \\
Cost (NPR/ha) & $58,725.43$ & $193,946.50$ & 149.13 & \\
Average cost (NPR/kg) & 62.14 & & \\
\hline
\end{tabular}




\subsection{Gross Margin Analysis of Vegetable Seed in the Study Area}

Profit per hectare followed the same ranking as cost and price per $\mathrm{kg}$ for all four vegetable seeds with onion seed having the highest gross margin (NPR.121,682) per ha followed closely by cauliflower seed (NPR.117,136), radish seed (NPR.47,640), and pea seed (NPR.27,131).

Table 4. Gross margin (NPR/ha) of vegetable seed in the study area.

\begin{tabular}{llll}
\hline Vegetable seed & Minimum & Maximum & Average \\
\hline Onion Seed $(\mathrm{N}=89)$ & $(65,567.70)$ & $332,957.90$ & $121,681.80$ \\
Cauliflower $(\mathrm{N}=22)$ & $(27,510.00)$ & $270,187.50$ & $117,136.33$ \\
Radish $(\mathrm{N}=77)$ & $(45,195.00)$ & $131,458.50$ & $47,640.15$ \\
Pea $(\mathrm{N}=26)$ & $(18,114.80)$ & $111,396.18$ & $27,131.18$ \\
\hline
\end{tabular}

(Source: Field Survey, 2017)

\subsection{The Benefit-cost Ratio of Major Vegetable Seed in the Study Area}

The profitability of cultivation based on the comparison of income to variable cost (Benefit-Cost ratio) ranked cauliflower seed as the most profitable vegetable seed crop
(1.78), followed closely by onion seed (1.68) and radish seed (1.52). Whereas, pea seed was slightly less profitable (1.27) as compared with other vegetable seed grown in the study. Nevertheless, the B:C ratio shows that cultivation of all major four vegetable seeds were profitable enterprises.

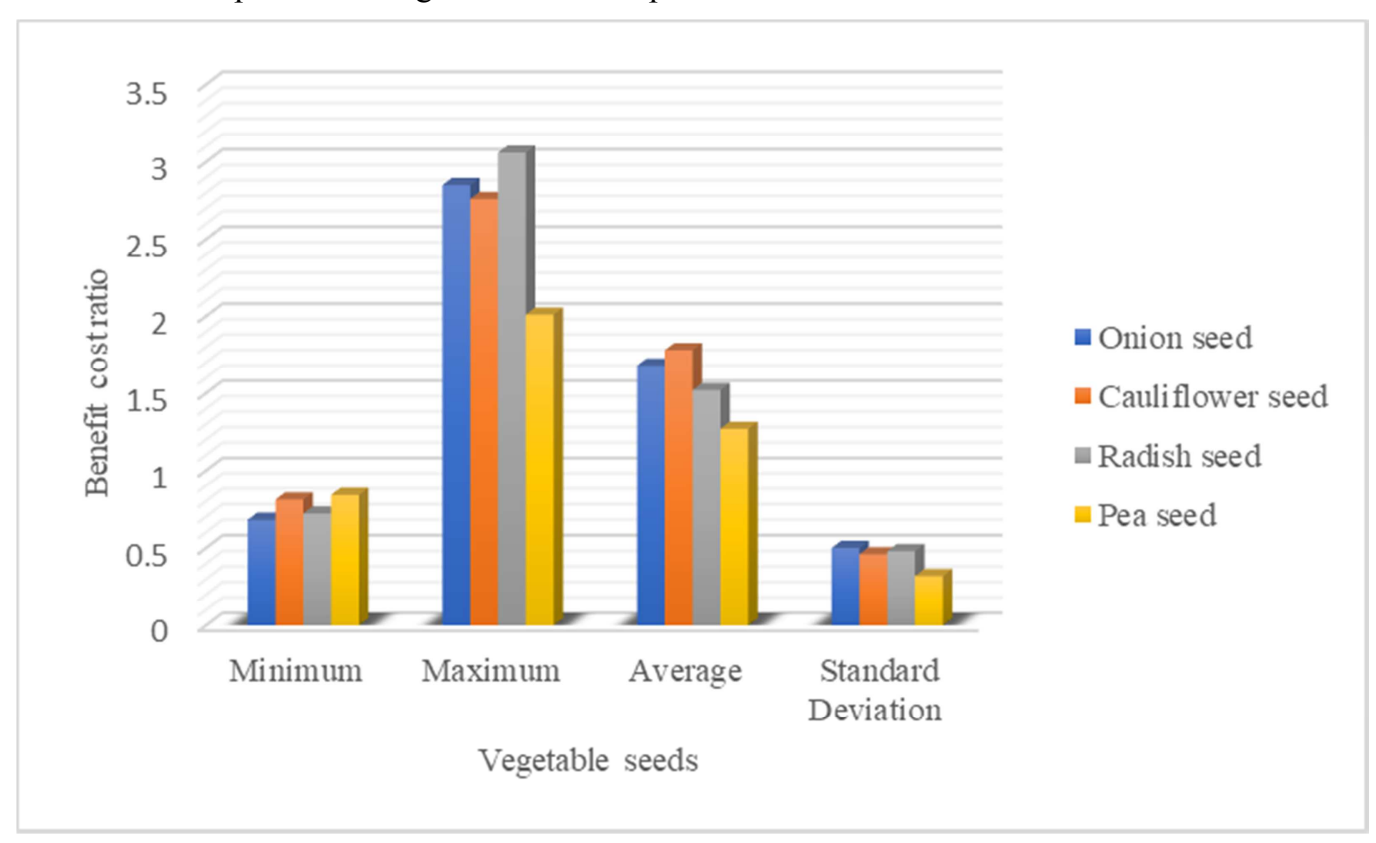

(Source: Field Survey, 2017).

Figure 3. Benefit cost ratio of major vegetable seeds in the study area.

\subsection{Resource Productivity of the Major Vegetable Seed}

\subsubsection{Resource Productivity of Onion Seed}

The variables used in the resource productivity of onion seed are described in Table 5 .

Table 5. Description of variables used in analysis of the resource productivity of onion seed.

\begin{tabular}{|c|c|c|c|c|c|}
\hline Variable & Observation (Obs.) & Mean & Std. Dev. & Min. & Max. \\
\hline Dependent variables & & & & & \\
\hline $\begin{array}{l}\text { Income from onion seed } \\
\text { Independent variable }\end{array}$ & 89 & 24321.4 & 14052.3 & 6300 & 68000 \\
\hline Labour cost & 89 & 8782.7 & 2944.12 & 3250 & 16500 \\
\hline Seed cost & 89 & 2647.75 & 1324.25 & 400 & 7500 \\
\hline Fertilizers cost & 89 & 975.73 & 578.89 & 220 & 4000 \\
\hline Manure cost & 89 & 851.85 & 665.51 & 0 & 3200 \\
\hline Other costs & 89 & 97.08 & 403.90 & 0 & 3000 \\
\hline
\end{tabular}


Labour cost, seed cost, fertilizers cost, manure cost, pesticides cost, and other costs (irrigation, inspection, grading material) incurred on onion seed production were considered to estimate a simple linear regression model to determine resource productivity of the onion seed production. The labour cost, seed cost, fertilizer cost, manure cost, and pesticide cost for onion seed production were positively significant while the other cost required for onion seed production was found negatively significant. The labour cost, seed cost, and pesticide cost were statistically significant at a $1 \%$ level whereas the manure cost was significant at a $5 \%$ level. Per unit price increase in cost for labour for onion seed cultivation increases the income from onion seed by 2.07 units. An increase in the per-unit cost of seeds for onion seed production increases the income by 2.01 units. In the case of manure cost for onion seed production, per unit increase in cost, income from onion seed increases by 3.1 units. While per unit increase in the cost of pesticide for onion seed production increases the income from onion seed by 11.9 units. The model is significant at a $1 \%$ level with $\mathrm{R}^{2} 0.847$. Table 6 depicts the result of the resource productivity of onion seed production.

Table 6. Result of resource productivity of onion seed production.

\begin{tabular}{|c|c|c|c|c|c|c|}
\hline Variable & Coef. & Std. Err. & $\mathbf{t}$ & $P>t$ & [95\% Conf. & Interval] \\
\hline Labour cost & $2.073 * * *$ & .292 & 7.10 & 0.000 & 1.492 & 2.653 \\
\hline Seed cost & $2.019 * * *$ & .602 & 3.35 & 0.001 & .822 & 3.217 \\
\hline Fertilizers cost & .727 & 1.145 & 1.51 & 0.136 & -.552 & 4.006 \\
\hline Manure cost & $3.176 * *$ & 1.280 & 2.48 & 0.015 & .629 & 5.724 \\
\hline Pesticides cost & $11.924 * * *$ & 2.545 & 4.69 & 0.000 & .861 & 16.986 \\
\hline Other costs & -.256 & 1.551 & -0.17 & 0.869 & -3.343 & 2.830 \\
\hline
\end{tabular}

\begin{tabular}{ll}
\hline Summary Statistics & \\
\hline Number of observations & 89.000 \\
F $(6,82)$ & 75.720 \\
Prob $>$ F & 0.000 \\
R-squared & 0.847 \\
\hline
\end{tabular}

(Source: Field Survey, 2017).

\subsubsection{Resource Productivity of Cauliflower Seed}

The variables used in the resource productivity of cauliflower seed are described in Table 7.

Table 7. Description of variables used in analysis of the resource productivity of cauliflower seed.

\begin{tabular}{lllll}
\hline Variable & Obs. & Mean & Std. Dev. & Min. \\
\hline $\begin{array}{l}\text { Dependent variables } \\
\text { Income from cauliflower seed }\end{array}$ & 22 & 19722.7 & & \\
Independent variable & & & 8079.42 & 6000 \\
Labour cost & 22 & 8738.64 & 2937.56 & 32400 \\
Seed cost & 22 & 397.73 & 162.19 & 200 \\
Fertilizers cost & 22 & 607.73 & 400.25 & 0 \\
Manure cost & 22 & 2090.91 & 968.51 & 700 \\
Pesticides cost & 22 & 438.64 & 238.51 & 13000 \\
Other costs & 22 & 41.36 & 115.15 & 0 \\
\hline
\end{tabular}

All the variables, labour cost, seed cost, fertilizers cost, manure cost, pesticides cost, and other costs for cauliflower seed production were positively significant. The cost required for pesticides for cauliflower seed production was significant at $10 \%$ level. Per unit increase in the cost of pesticides for cauliflower seed production increases the income from cauliflower seed by 13.8 units. The model is significant at a $1 \%$ level with $\mathrm{R}^{2} 0.94$ and adjusted $\mathrm{R}^{2} 0.922$. Table 8 depicted the result of the resource productivity of cauliflower seed production.

Table 8. Result of resource productivity of cauliflower seed production.

\begin{tabular}{lllllll}
\hline Variables & Coef. & Std. Err. & T & P>t & Interval] & [95\% Conf. \\
\hline Labour cost & .657 & .561 & 7.259 & 1.17 & 0.260 & -.538 \\
Seed cost & 9.154 & 1.887 & 0.84 & 0.227 & -6.317 \\
Fertilizers cost & 1.582 & 1.015 & 0.96 & 0.415 & -2.440 \\
Manures cost & .973 & 6.575 & 2.11 & 0.353 & -1.190 \\
Pesticide cost & $13.866^{*}$ & 4.675 & 0.63 & 0.052 & -.148 \\
Other costs & 2.934 & 41638.840 & 0.54 & 0.540 & -7.031 \\
Constant & 22484.180 & & 0.597 & -604 & -66266.910 \\
\hline
\end{tabular}




\begin{tabular}{ll}
\hline Summary Statistics & \\
\hline Number of observations & 22.000 \\
F $(6,82)$ & 42.400 \\
Prob $>$ F & 0.000 \\
R-squared & 0.944 \\
Adjusted R-squared & 0.922 \\
Root MSE & 44327 \\
\hline
\end{tabular}

Note: *indicate significant $10 \%$ level.

(Source: Field Survey, 2017).

\subsubsection{Resource Productivity of Radish Seed}

The variables used in the resource productivity of radish are described in table 9.

Table 9. Description of variables used in analysis of the resource productivity of radish seed.

\begin{tabular}{|c|c|c|c|c|c|}
\hline Variable & Obs. & Mean & Std. Dev. & Min & Max \\
\hline \multicolumn{6}{|l|}{ Dependent variables } \\
\hline Income from radish seed & 77 & 19401.5 & 14016.2 & 3600 & 90000 \\
\hline \multicolumn{6}{|l|}{ Independent variable } \\
\hline Labour cost & 77 & 8753.9 & 4126.88 & 2500 & 21500 \\
\hline Seed cost & 77 & 373.9 & 222.1 & 100 & 1500 \\
\hline Fertilizers cost & 77 & 1183.64 & 1016.43 & 100 & 7000 \\
\hline Manure cost & 77 & 1423.64 & 1000.36 & 0 & 4000 \\
\hline Pesticides cost & 77 & 346.82 & 282.61 & 0 & 1200 \\
\hline Other costs & 77 & 78.44 & 147.92 & 0 & 800 \\
\hline
\end{tabular}

All the labour cost, seed cost, fertilizers cost, manure cost, pesticides cost, and other costs for radish seed production were positively significant. The seed cost and fertilizers cost were statistically significant at a $1 \%$ level whereas the manure cost was significant at a $5 \%$ level and pesticides cost was significant at a $10 \%$ level.

Per unit cost increase of labour for radish seed production increases the income from radish seed by 36.33 units. Similarly, increase in per-unit cost of fertilizers for radish seed production increases the income by 2.62 units. In the case of manure cost for radish seed production, an increase in per-unit cost, income from radish seed increases by 1.65 units. While per unit increase in the cost of pesticides for radish seed production increases the income from radish seed by 5.05 units. The model is significant at a $1 \%$ level with $\mathrm{R}^{2}$ 0.908 and adjusted $R^{2} 0.900$. Table 10 depicts the result of the resource productivity of radish seed production.

Table 10. Result of resource productivity of radish seed production.

\begin{tabular}{|c|c|c|c|c|c|c|}
\hline Variable & Coef. & Std. Err. & $\mathbf{T}$ & $P>t$ & [95\% Conf. & Interval] \\
\hline Labour cost & .130 & .239 & 0.55 & 0.587 & -.346 & .606 \\
\hline Seed cost & $36.333 * * *$ & 4.791 & 7.58 & 0.000 & 26.779 & 45.888 \\
\hline Fertilizers cost & $2.628 * * *$ & .944 & 2.78 & 0.007 & .746 & 4.511 \\
\hline Manure cost & $1.652 * *$ & .770 & 2.15 & 0.035 & .116 & 3.186 \\
\hline Pesticides cost & $5.058 *$ & 3.026 & 1.67 & 0.099 & -.980 & 11.096 \\
\hline Other costs & .204 & 4.710 & 1.10 & 0.273 & -4.190 & 14.599 \\
\hline
\end{tabular}

\begin{tabular}{ll}
\hline Summary Statistics & \\
\hline Number of observations & 77.000 \\
F $(6,82)$ & 115.020 \\
Prob $>$ F & 0.000 \\
R-squared & 0.908 \\
Adjusted R-squared & 0.900 \\
Root MSE & 8709 \\
\hline
\end{tabular}

Note: $* * *, * *$ and $*$ indicate significant at $1 \%, 5 \%$ and $10 \%$ level, respectively.

(Source: Field Survey, 2017).

\subsubsection{Resource Productivity of Pea Seed}

The variables used in the resource productivity of pea are described in table 11. 
Table 11. Description of variables used in analysis of the resource productivity of pea seed.

\begin{tabular}{|c|c|c|c|c|c|}
\hline Variable & Obs. & Mean & Std. Dev. & Min. & Max. \\
\hline $\begin{array}{l}\text { Dependent variables } \\
\text { Income from pea seed } \\
\text { Independent variable }\end{array}$ & 26 & 10103.9 & 6504.19 & 3750 & 25000 \\
\hline Labour cost & 26 & 5775 & 2728.75 & 2250 & 13500 \\
\hline Seed cost & 26 & 571.15 & 307.63 & 150 & 1200 \\
\hline Fertilizers cost & 26 & 436.35 & 320.47 & 0 & 1150 \\
\hline Manure cost & 26 & 415.38 & 178.2 & 200 & 1000 \\
\hline Other costs & 26 & 96.15 & 97.11 & 0 & 375 \\
\hline
\end{tabular}

All the labour cost, seed cost, fertilizers cost, manure cost, pesticides cost, and other costs for pea seed production were positively significant. The labour cost and seed cost were significant at a $1 \%$ level and fertilizer cost and other costs required for pea production were significant at a $10 \%$ level.

Per unit cost increase of labour cost for pea seed production increases the income from pea seed production by 0.79 units. Increase in per-unit cost of seed for pea seed production increase the income by 6.99 unit. In the case of fertilizers cost for pea seed production, an increase in perunit cost, income from pea seed increases by 3.82 units. While per unit increase in other costs for pea seed production increases the income from pea seed by 11.63 units. The model is significant at a $1 \%$ level with $\mathrm{R}^{2} 0.935$ and adjusted $\mathrm{R}^{2}$ 0.914. Table 12 depicts the result of the resource productivity of pea seed production.

Table 12. Result of resource productivity of pea seed production.

\begin{tabular}{|c|c|c|c|c|c|c|}
\hline Variables & Coef. & Std. Err. & $\mathbf{T}$ & $P>t$ & [95\% Conf. & Interval] \\
\hline Labour cost & $.792 * * *$ & .235 & 3.37 & 0.003 & .3001 & 1.283 \\
\hline Seed cost & $6.997 * * *$ & 2.315 & 3.02 & 0.007 & 2.151 & 11.841 \\
\hline Fertilizers cost & $3.829 * *$ & 1.471 & 2.60 & 0.017 & .750 & 6.907 \\
\hline Manure cost & 5.410 & 3.859 & 1.40 & 0.177 & -2.667 & 13.489 \\
\hline Pesticides cost & .690 & 3.441 & 0.20 & 0.843 & -6.511 & 7.892 \\
\hline Other costs & $11.633^{* *}$ & 5.400 & 2.15 & 0.044 & .332 & 22.935 \\
\hline
\end{tabular}

\begin{tabular}{ll} 
Summary Statistics & \\
\hline Number of observations & 26.000 \\
F $(6,82)$ & 45.260 \\
Prob $>$ F & 0.000 \\
R-squared & 0.935 \\
Adjusted R-squared & 0.914 \\
Root MSE & 3749 \\
\hline
\end{tabular}

Note: $* * *$ and $* *$ indicate significant at $1 \%$ and $5 \%$ level, respectively.

(Source: Field Survey, 2017).

\section{Conclusion and Policy Recommendation}

The study was executed to explore the cost, return, and profitability of major vegetable seed in the Western Rukum district of Nepal. This district was the major contributor to national seed production. Two urban municipalities namely Musikot and Chaurjahari; and two rural municipalities namely Sani Bheri and Triveni were the major areas for vegetable seed production in the district, where 1010 vegetable seed producers were associated in 44 farmers groups registered in the District Agriculture Development Office, Rukum. In total, 13 types of vegetable seeds were grown in the district. Among them, onion seed, radish seed, cauliflower seed, and pea seed were the major vegetable seed crops. Red Creole, Mino Early, Kathmandu Local, and Sikkime Local were the major varieties used by farmers for producing seed of onion, radish, cauliflower, and pea, respectively. There was an unmet demand for vegetable seed within the nation having export potentiality. The result shows that the cultivation of all four-vegetable seeds was profitable. However, comparing four crops, cost and return on production of both per $\mathrm{kg}$ seed, and in per hectare of land for onion seed was the highest following cauliflower seed, radish seed, and pea seed. Similarly, gross margin per hectare of land also followed the same rank. Whereas, the benefit-cost ratio $(\mathrm{B}: \mathrm{C})$ of the cauliflower seed was the highest followed by onion seed, radish seed, and pea seed. This study recommends farmers to increase investment in vegetable seed production maintaining the quality of the production. Besides, concerned stakeholders and policymakers need to emphasis on the promotion of vegetable seed production focusing on enhancing market linkage and farmers' technical know-how. 


\section{Conflicts of Interest}

The authors declare that they have no competing interests.

\section{References}

[1] AICC, A. I. (2016). Krishi Diary. Ministry of Agriculture Development.

[2] Belay, G., Yami, M., Bekele, A. (2020). Analysis of Costs of Production and Profitability for Irrigated Cotton under Smallholder Production Systems; the Case of Middle Awash Valley. Ethiopian Journal of Agricultural Science, 30 (1) 1-16.

[3] CEAPRED. (2013). Market Information Study Analyzing National Demand, Supply, Import, and Export Situation of Vegetable Seeds in Nepal. Centre for Environmental and Agricultural Policy Research, Extension and Development.

[4] DADO. (2015). Rukum Jilla ma biu utpadan sthiti, sambabhana, aabasar ra cunauti tatha jilla krisi bikas karyalaya ko bhumika (in Nepali). Rukum: District Agriculture Development Office, Government of Nepal.

[5] DADO. (2016). Annual agriclture development program and statistical glimpse. Rukum, District Agriulture Development Office.

[6] DDC-Rukum. (2013). District Profile of Rukum 2070. Rukum, Nepal: District Development Committee (DDC).

[7] Dhakal S. C. et al. (2015). Resource use efficiency of mustard production in Chitwan district of Nepal. International Journal of Applied Science and Biotechnology, Vol 3 (4): 604-608.

[8] Karki, Y. K. (2015). Nepal portfolio performance review. Ministry of agricultural development.
[9] KUBK. (2016). Vegetables Seed Value Chain Report. Kisankalagi Unnat Biu-Bijan Karyakram (KUBK), Ministry of Agriculture Development, Government of Nepal.

[10] MOAD. (2013). National seed vision 20132025 (seed sector development strategy). Government of Nepal, Ministry of Agriculture Development.

[11] MOAD. (2014). Statistical information on Nepalese agriculture 2013/2014. Singhadurbar, Kathmandu: Ministry of Agriculture.

[12] MoF. (2017). Economic Survey. Mistry of Finance, Government of Nepal, Kathmandu.

[13] Ojha, E. R. (2016). End term evaluation of vegetable seed production program, 2013-2015. Thapathali, Kathmandu: United Missin to Nepal.

[14] Sankala, G. (2015). Production function and resource use efficiency of milk in different categories of member and nonmember families of dairy cooperatives in Jaipur (Rajasthan). Indian Journal of Dairy Sciences, 68 (5).

[15] SCPL. (2011). A report on vegetable value chain analysis of vegetable seeds in Nepal. High-Value Agriculture Project in Hill and Mountain Areas. Birendranagar, Surkhet, Nepal: Solution Consultant Private Limited.

[16] SVSPC. (2016). Annual progress booklet. Chanpa, Rukum, Nepal: Subtropical Vegetable Seed Production Center.

[17] UMN. (2015). Annual Progress Report, United Mission to Nepal (UMN), Rukum-Cluster, and Vegetable Seed Production Cooperative Association. Musikot-1, Rukum. 